\title{
Az új típusú koronavírus okozta megbetegedés (COVID-19): összefoglaló hematológusoknak II. - a diagnosztika, terápia és prevenció lehetőségei
}

\author{
Szabó Bálint Gergely ${ }^{1,2,3, @}$, Bobek Ilona ${ }^{1}$, Réti Marienn ${ }^{1}$, Gopcsa Lászlón ${ }^{1}$ Mathiász Dóra ${ }^{1}$, \\ Lakatos Botond $^{1}$, Bekő Gabriella ${ }^{1}$, Pető Mónika ${ }^{1}$, Sinkó János ${ }^{1}$, Mikala Gábor ${ }^{1}$, Kis Zoltán ${ }^{3}$, \\ Szlávik János ${ }^{1}$, Reményi Péter ${ }^{1}$, Vályi-Nagy István ${ }^{1}$ \\ ${ }^{1}$ Dél-pesti Centrumkórház, Országos Hematológiai és Infektológiai Intézet (Budapest) \\ ${ }^{2}$ Semmelweis Egyetem, Klinikai Tudományok Doktori Iskola (Budapest) \\ ${ }^{3}$ Nemzeti Népegészségügyi Központ (Budapest)
}

\begin{abstract}
A COVID-19 a SARS-CoV-2 vírus által okozott, járványosan terjedő, légúti kiindulású betegség. A kórokozó magas patogenitású, zoonotikus eredetű humán coronavírus, mely hatékonyan terjed emberről emberre cseppfertőzéssel és közeli kontaktussal. A vírusdiagnosztika a légutakból vett minta PCR-vizsgálatán alapul, melynek ismétlésére szükség lehet a fertőzés kizárására. A PCR-eredményt a klinikummal egybe kell vetni, mivel a preszimptomatikus beteg már vírust üríthet, a gyógyultak PCR-pozitivitása pedig hetekig elhúzódik. A terápiás stratégiák két ágát az antivirális gyógyszerek, valamint a hiperinflammációt gátló immunmodulánsok adják. Jelen összefoglalásunk a második azon két társközlemény közül, melyek célja a 2020. május 25-ig elérhető legfőbb nemzetközi és hazai betegséggel kapcsolatos eredmények ismertetése, elsősorban, de nem kizárólag hematológus kollégák számára.
\end{abstract}

Kulcsszavak: COVID-19, SARS-CoV-2, világjárvány, citokinvihar

The novel coronavirus disease (COVID-19): a review for specialists in hematology II - aspects of diagnosis, therapy and prevention

COVID-19 is a pandemic infection caused by SARS-CoV-2, a highly pathogenic human coronavirus with zoonotic origin which is efficiently transmitted by air droplets and close contact. The laboratory diagnosis is based on the PCR of respiratory secretions, and multiple re-samplings might be needed to rule out infection. PCR results should be correlated to clinical symptomatology, as presymptomatic people can already shed the virus, whereas PCR positivity of reconvalescent patients could be ongoing for weeks. Therapeutic strategies are based on antiviral medications and hiperinflammation inhibiting immunomodulation. The present review is the second of two co-publications which aim to summarize the international and Hungarian literature of COVID-19 as of May 25, primarily but not exclusively for specialists in hematology.

Keywords: COVID-19, SARS-CoV-2, pandemic, cytokine storm

(Beérkezett: 2020. június 1.; elfogadva: 2020. június 15.)

@ Levelezési cím: Dr. Szabó Bálint Gergely, Dél-pesti Centrumkórház, Országos Hematológiai és Infektológiai Intézet, 1097 Budapest, Albert Flórián út 5-7., Tel.: 06-1/455-8100/8469 


\section{Rövidítések}

ACE2 = angiotenzin-konvertáló enzim 2 (angiotensin converting enzyme 2 receptor); $\mathrm{ADE}$ = antitestdependens erősítés (antibody dependent enhancement); ARDS = akut légzési distressz szindróma (acute respiratory distress syndrome); AZI = azithromycin; $\mathrm{BAL}=$ bronchoalveolaris lavázs (broncholalveolar lavage) $\mathrm{CD}=$ differenciációs klaszter (cluster of differentiation); CMIE = kemolumineszcens mikropartikulum immunoassay (chemiluminescent microparticle immunoassay); COVID-19 = coronavírus betegség-19 (coronavirus disease-19); CQ = chloroquin; CRS = citokinfelszabadulási szindróma (cytokine release syndrome); $\mathrm{DAD}=$ diffúz alveoláris károsodás (diffuse alveolar damage); DIC = diszszeminált intravaszkuláris koaguláció (disseminated intravascular coagulation); ELISA = enzimhez kötött immunoszorbens assay (enzyme-linked immunosorbent assay); $\mathrm{ER}=$ endoplazmatikus retikulum (endoplasmatic recitulum); $\mathrm{FiO}_{2}=$ belégzési $\mathrm{O}_{2}$-frakció (fraction of inspired oxigen); FVP = favipiravir; HAP = egészségügyi ellátással összefüggő pneumonia (healthcare-acquired pneumonia); $\mathrm{HLH}=$ haemophagocytás lymphohistiocytosis (haemophagocytic lymphohystiocytosis); HMPV = humán metapneumovírus (human metapneumovirus); HCQ = hidroxychloroquin; ICU = intenziv terápiás osztály (intensive care unit); IFN = interferon (interferon); IPA = invazív tüdőaspergillosis (invasive pulmonary aspergillosis); IVIG = intravénás immunglobulin; LPV/r = lopinavir/ritonavir; MAS = macrophag aktivációs szindróma (macrophag activation syndrome); MBL = mannózkötő lektin (mannose binding lectin); MSC = mesenchymalis össejt (mesenchymal stem cell); NK = természetes ölösejt (natural killer); MERS-CoV = közel-keleti légzőszervi szindróma coronavírus (Middle Eastern Respiratory Syndrome Coronavirus); $\mathrm{PaO}_{2}=$ artériás parciális $\mathrm{O}_{2}$-tenzió (partial pressure of $\mathrm{O}_{2}$ ); $\mathrm{PCR}=$ polimeráz láncreakció (polymerase chain reaction); $\mathrm{R}_{0}=$ elemi reprodukciós szám (basic reproduction number); RBD = receptorkötő domén (receptor binding domain); RDV = remdesivir; RNS = ribonukleinsav (ribonucleic acid); RSV = légzőszervi szinciciális vírus (respiratory syncytial virus); RT-PCR = valós idejű polimeráz láncreakció (real-time PCR); SARS = súlyos akut légzőszervi szindróma (severe acute respiratory syndrome); SARS-CoV-1 = súlyos akut légzőszervi szindróma coronavírus-1 (Severe Acute Respiratory Syndrome Coronavirus-1); SARS-CoV-2 = súlyos akut légzőszervi szindróma coronavírus-2 (Severe Acute Respiratory Syndrome Coronavirus-2); SIRS = szisztémás gyulladásos válaszreakció szindróma (systemic inflammatory response syndrome); $\mathrm{SpO}_{2}=$ perifériás $\mathrm{O}_{2}$-szaturáció (peripheral saturation of $\mathrm{O}_{2}$ ); TMPRSS2 $=$ transzmembrán szerin-proteáz 2 (transmembrane protease, serine 2); VAP = lélegeztetéssel összefüggő pneumonia (ventilator-associated pneumonia); VTM = vírustranszportmédium (virus transport medium); WHO = Egészségügyi Világszervezet (World Health Organization)

\section{Bevezetés}

Jelen összefoglalásunk a második azon két társközlemény közül, melyek célja, hogy a 2020. május 25 -ig elérhető hazai és nemzetközi irodalmi adatok alapján ismertesse a COVID-19-cel kapcsolatos legfontosabb tudnivalókat elsősorban, de nem kizárólag a hematológus olvasók számára. Ennek kapcsán a közleményben tárgyalásra kerül a fertőzés diagnosztikája, súlyossági stratifikációja és prognosztikája, valamint kezelésének és prevenciójának lehe- tőségei. A közleményben kitérünk a malignus hematológiai betegségben szenvedôket érintő speciális szempontokra is.

A téma iránt érdeklődő olvasó számára további tájékozódás céljából ajánljuk az Orvostovábbképző Szemlében megjelent, online szabadon hozzáférhető összefoglalót (Szabó Bálint Gergely: „Egy új világjárvány közepén amit eddig a COVID-19-ről tudni vélünk"), továbbá javasoljuk a COVID-19-cel kapcsolatos aktuális magyar eljárásrend áttekintését az nnk.gov.hu oldalon [1].

A hematológiai betegek ellátásával kapcsolatos speciális teendők betegségenkénti bontásban az American Society of Hematology (www.hematology.org/covid-19) és a European Hematology Association (www.ehaweb.org/covid-19) honlapjain rendszeresen frissítve olvashatóak.

\section{A COVID-19 diagnosztikája}

\section{A COVID-19 molekuláris virológiai diagnosztikája}

A pandémia jelenlegi stádiumában kívánatos minden epidemiológiailag vagy klinikailag gyanús esetet SARSCoV-2 irányába tesztelni. A COVID-19 akut diagnosztikája a vírusgenom légúti jelenlétének PCR-rel való kimutatásán alapszik. A vizsgálatra alkalmas minta a légúti epithelsejteket bőségesen tartalmazó légúti váladék. Spontán légző betegnél ezt az oro- és nasopharynx átnedvesített vattával történő erélyes, min. 10 másodperces törlésével vehetjük le. Az elülső orrkagyló, a torokszoros, bucca, gingiva, mandulák és nyelvgyök nem alkalmas anatómiai lokalizációk a mintavételre. A mintavevő pálca műanyag szárú, múszálas vagy müsörtés fejű lehet. A mintavétel hatásfokát növeli, ha a személy a mintavétel előtt 8-12 órával már nem eszik-iszik, nem dohányzik, fogmosást és szájtoalettet nem végez. Intubált betegnél a bronchoalveolaris lavage (BAL), mini-BAL és endotrachealis aspirátum is alkalmas vizsgálatra. A vattapálcákat vagy az egyéb módon vett mintát az erre a célra rendszeresített folyékony vírustranszport-médiumba (VTM) szükséges alaposan bemosni. A vattába ivódott folyadékot a cső oldalán óvatosan ki kell nyomkodni. A minta bemosása általában akkor sikeres, ha a VTM oldata megtörtté válik. A mintát $2-8{ }^{\circ} \mathrm{C}$-on 72 órán, szobahőmérsékleten 24 órán át lehet tárolni, de a diagnózis gyorsítása érdekében érdemes azt minél hamarább a Nemzeti Népegészségügyi Központ (NNK) eljárásrendjében kijelölt laboratóriumok egyikébe juttatni.

Tünetes betegnél a SARS-CoV-2 PCR-pozitivitás megerősíti a COVID-19 fertőzés diagnózisát. A jelenleg forgalmazott SARS-CoV-2 kitek specificitása a PCR-primer targetjétől függetlenül gyakorlatilag $100 \%$. A PCR szenzitivitását és negatív prediktív értékét szisztematikusan még nem értékelték, azonban valószínủleg egyik sem teljes. Egy nemrég publikált tanulmány alapján a PCR-vizsgálat szenzitivitása erősen függ a mintatípustól: 
a BAL-minták 93\%-a, a köpet $72 \%$-a, az orrgarattörlet 63\%-a, a szájgarattörlet $32 \%$-a lett pozitív tünetes betegnél [2]. A PCR-re történő mintavétel optimális időpontja valószínúleg a tünetkezdet utáni 1-3 nap, ennél hamarabb a téves negatív eredmények aránya magasabb lehet (különösen alacsony pre-test valószínüség esetén) [3]. A mintavétel hibalehetőségeinek, valamint a fenti adatok fényében az egyszeri és korai negatív PCR-vizsgálat negatív prediktív értéke alacsony. Fennálló klinikai gyanú esetén legalább 48 óra múlva ismételt PCR-vizsgálat végzendő, ügyelve a szabályos mintavételre, mivel ekkorra a légúti vírusreplikáció már elérheti a PCR detekciós küszöbét.

A szerodiagnosztika akut fertőzés igazolására vagy kizárására nem, a tünetmentes átvészeltség vagy enyhe tünetek miatt orvoshoz nem forduló betegek szerokonverziójának későbbi ellenőrzésére azonban alkalmas módszer lehet. Emellett populációs szintü epidemiológiai adatokat szolgáltathat a háttérimmunitásról, vagy nozokomiális környezetben az átfertőzöttség mértékéről. Az elérhető szerológiai vizsgálatok tényleges szenzitivitása egyelőre kérdéses. A tesztek összesített teljesítőképessége valószínűleg növelhető, ha több immundomináns antigén elleni szerológiai kitet is alkalmazunk (pl. kétlépcsős eljárásban). A jelenleg forgalomban lévő, validált kitek CMIE (chemiluminescent microparticle immunoassay) vagy ELISA (enzyme-linked immunosorbent assay) elven detektálják a szerokonverzió létrejöttét. Fontos azonban tudnunk, hogy az össztiterből a védettséget biztosító neutralizáló antitestek jelenlétét csak az ún. plakkredukciós neutralizációs teszttel lehet meghatározni, ami speciális laborhátteret és időt igényel. A fentiek mellett lehetséges, hogy a SARS-CoV-2 szerodiagnosztikája során, az alacsony patogenitású humán coronavírusok ellen termelődött antitestek jelenléte miatt, számolni kell keresztreaktivitással, ez pedig ront a tesztek specificitásán [2]. Egy ideje elterjedőben vannak a különféle gyártók által forgalmazott szerológiai gyorstesztek is, melyek általában lateral flow assay alapúak. Ezek teljesítőképessége erősen kétséges, így nem szolgálhatják a klinikai diagnosztikát. Két jelenleg forgalmazott gyorsteszt pontatlanságára egy magyar felmérés is felhívta a figyelmet [4].

A PCR és szerológiai leletek eredményei alapján lehetséges klinikai interpretációkat a 1. táblázat összegzi. A táblázatból láthatjuk, hogy a negatív eredmények nem feltétlenül zárják ki, míg pozitív eredmények nem szükségszerűen erősítik meg az aktívan zajló infekció diagnózisát. A leletet minden esetben össze kell vetni a beteg panaszaival, és a feltételezett klinikai stádiummal.

\section{A COVID-19 labor-és képalkotó diagnosztikája}

A COVID-19 számos, tipikusnak mondható laboreltérést produkál diagnóziskor, és azt követően is. E markerek egy része valószínűleg előre jelzi a kedvezőtlen kimenetelt. A vérképben kb. 70-80\%-ban abszolút lymphopeniát látunk leukopenia, valamint thrombocytopenia (35-50\%) mellett. A leukocytosis nem típusos (4-11\%). A myeloid vonal 60-70\%-ban szupprimált - jellegzetes a kifejezett eosinopenia -, a granulocytopenia egyébként ép csontvelői rezerv mellett nem számottevő mértékü. Újkeletű leukocytosis vagy abszolút neutrofília szekunder bakteriális infekció vagy candidemia kísérője lehet, míg a romló pancytopenia fenyegető vagy zajló citokinvihart gyanúját erősítheti. A vérkép mért adataiból származtatott paraméterek, mint pl. a neutrophil/lymphocyta vagy thrombocyta/lymphocyta arány alkalmasak lehetnek a gyulladásos csontvelői szuppresszió mértékének követésére [5-7].

Szövetkárosodásra utal az LDH-vezette necroenzimkiáramlás, melyet GOT-, GPT-, CK-emelkedés kísérhet. A metabolikus kisiklást laktát-, bilirubin- és kreatininemelkedés jelzi. A betegek ismeretlen hányadában reaktív antifoszfolipid antitestek jelennek meg, ezek funkcionális szerepe egyelőre pontosabb tisztázást igényel. A klasszikus alvadási idők (INR, aPTI, TI) mérsékelten megnyúlnak, ez DIC (disszeminált intravaszkuláris koaguláció)-szerü alvadási képet sugall, de a fibrinogénszint típusosan emelkedett. A citokinvihar/HLH (haemophagocytás lymphohistiocytosis) további laboratóriumi jele a hypertrigliceridemia, a progresszíven emelkedő CRP-, interleukin-6-, ferritin- és D-dimer-szint. Az utóbbi két marker a súlyos lymphopenia, thrombopenia és a cardialis sérülést jelző troponin-, valamint NT-proBNPkiáramlás mellett a korai halálozás független prediktora. A prokalcitonin értéke diagnóziskor a betegek 95\%-ában normál tartományba esik, perzisztáló emelkedése alternatív fertőző ágens kóroki szerepére (pl. szekunder bakteriális infekcióra) utalhat [5-8].

A COVID-19 képalkotó vizsgálatai során mellkasröntgen és mellkasi CT-vizsgálat végezhető. A mellkasröntgen szenzitivitása - így haszna - csekély. Az első napokban az enyhe tünetes betegek 15-20\%-a röntgenvizsgálattal negatív. Körükben a teljes betegség időtartama alatti negativitás szintúgy $20 \%$. Mellkasröntgenen leggyakrabban konszolidáció, és kétoldali, perifériás túlsúlyú gócos transzparenciacsökkenés mutatkozik. A szenzitívebb mellkasi CT-vizsgálat egyúttal a rizikóstratifikációt is támogatja. Fontos azonban tudni, hogy a mellkasi CT jelenleg nem általánosan és kötelezően javasolt vizsgálat a COVID-19 diagnózisának megállapítására. Elvégzésével ugyanis a betegséget egyértelmüen sem bizonyítani, sem kizárni nem lehet. Irodalmi adatok alapján a felvétel napján végzett mellkasi CT-vizsgálatok 50-85\%-a pozitív az összes hospitalizált beteg körében, míg a súlyos betegek esetében a CT-pozitivitás 95\% feletti [9]. A fertőzés egyértelmüen patognomikus CT-radiomorfológiával nem rendelkezik. Jelen ismereteink szerint a legspecifikusabb a kétoldali ( 85\%-ban), subpleuralis (80\%) és alsó lebenyi (70\%) dominanciájú, konfluáló tejüveghomályok (90\%) előfordulása (ground glass opacity, GGO), melyek a súlyosabb stádiumban, ill. a betegség progressziójával konszolidálnak (általában az 5-8. nap között). Az egyoldali manifesztáció (10\%), a pleuravastagodás (15\%) és leve- 
1. táblázat. A SARS-CoV2 fertőzés virológiai diagnosztikájában használt tesztek eredményeinek interpretációi

\begin{tabular}{|c|c|c|c|}
\hline \multicolumn{3}{|c|}{ Laboreredmény } & \multirow{2}{*}{ Interpretáció } \\
\hline$P C R^{*}$ & $\operatorname{Ig} M^{* *}$ & $\operatorname{Ig} G^{* *}$ & \\
\hline \multirow{7}{*}{ Pozitív } & & & 1. Preszimptomatikus fázisban lévő személy \\
\hline & Negatív & Negativ & 2. Akut fertőzés korai fázisa, szerokonverzió nem jött létre \\
\hline & & & 3. Rekonvaleszcens beteg elhúzódó PCR-pozitivitással, szerokonverzió nem jött létre \\
\hline & Neoatín & Pozitív & 1. Akut fertőzés késői fázisa \\
\hline & Negativ & Pozttiv & 2. Rekonvaleszcens beteg elhúzódó PCR-pozitivitással \\
\hline & Pozitív & Negativ & Akut fertőzés korai fázisa \\
\hline & Pozitív & Pozitív & $\begin{array}{l}\text { 1. Akut fertőzés késői fázisa } \\
\text { 2. Rekonvaleszcens beteg elhúzódó PCR-pozitivitással }\end{array}$ \\
\hline \multirow{7}{*}{ Negativ } & & & 1. Fogékony személy \\
\hline & Neratin & & 2. Preszimptomatikus fázisban lévő személy \\
\hline & Negativ & Negatıv & 3. Akut fertőzés korai fázisa, álnegatív PCR \\
\hline & & & 4. Rekonvaleszcens beteg, szerokonverzió nem jött létre \\
\hline & Negativ & Pozitív & $\begin{array}{l}\text { 1. Fogékony személy, álpozitív szerológiai eredmény } \\
\text { 2. Rekonvaleszcens beteg }\end{array}$ \\
\hline & Pozitív & Negatív & $\begin{array}{l}\text { 1. Fogékony személy, álpozitív szerológiai eredmény } \\
\text { 2. Akut fertőzés korai fázisa, álnegatív PCR }\end{array}$ \\
\hline & Pozitív & Pozitív & $\begin{array}{l}\text { 1. Akut fertőzés késői fázisa, álnegatív PCR } \\
\text { 2. Rekonvaleszcens beteg, perzisztáló IgM }\end{array}$ \\
\hline
\end{tabular}

* Szabályosan vett, felső vagy alsó légúti mintából készült RT-PCR alapján.

** Vérplazmából, validált módszerrel (pl. CMIE, ELISA) mért eredmény alapján. A gyorstesztek az elérhető klinikai adatok alapján a diagnózis felállítására megbízhatatlanok, így alkalmatlanok.

2. táblázat. Nem kritikus és kritikus állapotú, igazolt COVID-19 betegek kiegészítő (nyitó) mikrobiológiai vizsgálatainak lehetőségei

\begin{tabular}{|c|c|c|}
\hline Betegállapot & Klinikai minta típusa & Mikrobiológiai vizsgálat \\
\hline \multirow{8}{*}{ 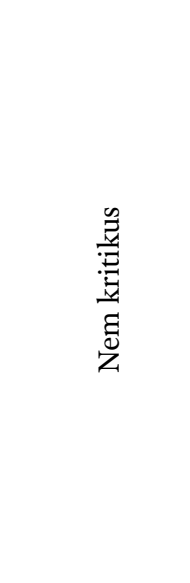 } & $\begin{array}{l}\text { Köpet } \\
\text { - valamennyi betegtől javasolt, ha a köhögés produktív }\end{array}$ & $\begin{array}{l}\text { Aerob bakt. tenyésztés + festett kenet mikroszkópos } \\
\text { vizsgálata }\end{array}$ \\
\hline & \multirow{4}{*}{$\begin{array}{l}2 \times 2 \text { hemokultúra } \\
\text { - valamennyi betegtől javasolt } \\
\text { - láz alatt vagy láztalanul, ha a beteg szeptikus vagy } \\
\text { antibiotikum indítása tervezett }\end{array}$} & Alapesetben: $2 \times 2$ palack frissen szúrt perifériáról \\
\hline & & Új centrálvénás kanül biztosítása esetén: $2 \times 2$ palack \\
\hline & & a centrálvénán át \\
\hline & & $\begin{array}{l}\text { Régi centrálvénás kanül bennléte esetén: } 2 \times 1 \text { palack a } \\
\text { kanülszárakon át }+2 \times 1 \text { palack frissen szúrt perifériáról }\end{array}$ \\
\hline & $\begin{array}{l}\text { Vizelet antigénteszt } \\
\text { - középsúlyos és súlyos esetben javasolt }\end{array}$ & $\begin{array}{l}\text { Vizelet Legionella sp. + vizelet pneumococcus antigén- } \\
\text { vizsgálat }\end{array}$ \\
\hline & $\begin{array}{l}\text { Elülső orrkagyló törlete } \\
\text { - középsúlyos és súlyos esetben javasolható }\end{array}$ & $\begin{array}{l}\text { MRSA szűrés (HAP empirikus antibiotikum-terápiájá- } \\
\text { ban van szerepe) }\end{array}$ \\
\hline & Köpet, esetleg orr-és torokgarat törlete & $\begin{array}{l}\text { Légúti vírus PCR, elsősorban influenza irányú diag- } \\
\text { nosztika javasolt }\end{array}$ \\
\hline \multirow{6}{*}{ 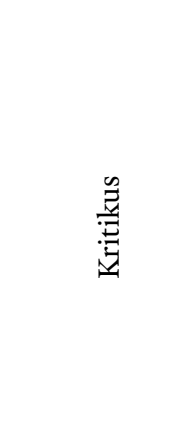 } & Hemokultúrák & Fentiek szerint \\
\hline & Vizelet antigénteszt & \\
\hline & Elülső orrkagyló törlete & \\
\hline & \multirow[t]{2}{*}{ Mini-BAL vagy BAL } & $\begin{array}{l}\text { Első frakció: légúti vírus PCR panel (elérhetőség } \\
\text { szerint) }\end{array}$ \\
\hline & & $\begin{array}{l}\text { Második frakció: aerob bakt. tenyésztés + gomba } \\
\text { tenyésztés + légúti galaktomannán teszt + festett kenet } \\
\text { mikroszkópos vizsgálata }\end{array}$ \\
\hline & Szérum gombamarkerek & $\begin{array}{l}\text { Szérum galaktomannán teszt + szérum béta-D-glukán } \\
\text { teszt }\end{array}$ \\
\hline
\end{tabular}


gö-bronchogram (15\%), a mellkasi lymphadenomegalia (3\%), kavitáció (3\%), és a jelentős pleuralis folyadék (4\%) viszonylag ritka. A radiomorfológia a klinikumhoz képest néhány nap késéssel, a 9-13. napon tetőzik, és a klinikai gyógyulást követően még hetekig kóros maradhat. Az ágy melletti, valamint sürgősségi képalkotást kiegészítheti a sorozatos mellkasi ultrahangvizsgálat (point of care ultrasound, POCUS), de a tapasztalatok egyelöre kis betegszámokon alapulnak [9-11].

\section{A COVID-19 kiegészitö mikrobiológiai diagnosztikája}

A súlyos és kritikus állapotú COVID-19 betegek körében a koinfekciók nem elhanyagolható valószínűsége, a centrumok közötti betegáthelyezések és empirikus antimikrobiás terápiák miatt elengedhetetlen, hogy a virológiai diagnosztikán kívül kiegészítő mikrobiológiai vizsgálatokat is végezzünk. A diagnóziskor javasolt, ún. nyitó mikrobiológiai vizsgálatokat a 2. táblázat szemlélteti. Kiemelt fontosságú a hemokultúrák és légúti minták levétele. A táblázat a szerzők munkahelyén követett klinikai gyakorlatot is tükrözi [12-14].

\section{A COVID-19 differenciáldiagnosztikája}

A COVID-19 differenciáldiagnosztikájában megtaláljuk a közösségben szerzett más légúti vírusok okozta pneumonitist (influenza!), ahogy az akut bakteriális pneumoniákat is. A hematológiai betegek körében megelőző kezelésüktől és immunstátuszuktól függően CMV-pneumonitisszel, ill. Pneumocystis jirovecii pneumoniával is számolnunk kell. Nem lehet figyelmen kívül hagyni, hogy a COVID-19 kardinális tünetei egybevágnak a más kiindulású szepszis, endocardialis/endovascularis vagy véráram-infekciók klinikumával is. A non-infektív etiológiák közül ki kell emelnünk az akut mellkasi szindrómákat (akut coronariaszindróma, akut aortaszindróma, tüdőembólia), a PTX-et, az akut szívelégtelenséget és a COPD akut exacerbációját. A hematológiai betegek körében a

3. táblázat. Igazolt COVID-19 betegek súlyossági stratifikációja, valamint a súlyos/kritikus COVID-19-be való progressziót előrejelző klinikai és biokémiai rizikófaktorok

\begin{tabular}{|c|c|}
\hline Súlyosság & Kritérium \\
\hline \multirow[t]{2}{*}{$\begin{array}{l}\text { Enyhe és középsúlyos betegség* } \\
\text { (valamennyi kritérium esetén) }\end{array}$} & $\begin{array}{l}\text { Enyhe: nincs nyugalmi vagy effort dyspnoe, tachypnoe (légzésszám }<22 / \text { perc), nincs } \mathrm{O}_{2-} \\
\text { igény + nincs pneumonia mellkasi képalkotáson }\end{array}$ \\
\hline & $\begin{array}{l}\text { Középsúlyos: dyspnoe, tachypnoe (légzésszám 22-29/perc) vagy } \mathrm{O}_{2} \text {-igény van } \pm \text { pneumonia } \\
\text { mellkasi képalkotáson }\end{array}$ \\
\hline \multirow{4}{*}{$\begin{array}{l}\text { Súlyos betegség } \\
\text { ( } \geq 1 \text { kritérium megléte esetén) }\end{array}$} & 1. Légzési distressz: légzésszám $\geq 30 /$ perc \\
\hline & $\begin{array}{l}\text { 2. Fizikális vizsgálattal hallható zörej és nyugalmi } \mathrm{O}_{2} \text {-szaturáció }\left(\mathrm{SpO}_{2}\right) \leq 93 \% \text { körlevegőn } \\
\text { vagy oxigénszükséglet: Venturi maszk }>50 \%\end{array}$ \\
\hline & 3. Artériás parciális $\mathrm{O}_{2}$-tenzió $\left(\mathrm{PaO}_{2}\right) /$ belégzési $\mathrm{O}_{2}$-frakció $\left(\mathrm{FiO}_{2}\right) \leq 300 \mathrm{Hgmm}$ \\
\hline & $\begin{array}{l}\text { 4. mellkasi CT-vel vizsgálva a tüdőben multilobularis lesiók vagy a tüdő infiltratumok } \\
50 \% \text {-os progressziója } 24-48 \text { óra alatt }\end{array}$ \\
\hline \multirow{6}{*}{$\begin{array}{l}\text { Kritikus állapotú betegség } \\
\text { ( } \geq 1 \text { kritérium megléte esetén) }\end{array}$} & 1. $\mathrm{SpO}_{2} \leq 90 \%, \mathrm{FiO}_{2}>100 \%$ oxigénszükséglet mellett \\
\hline & 2. $\mathrm{PaO}_{2} / \mathrm{FiO}_{2} \leq 200 \mathrm{Hgmm}$ \\
\hline & 3. Gépi lélegeztetést igénylő akut légzési elégtelenség \\
\hline & 4. ARDS radiomorfológiai képe \\
\hline & 5. Sokk, beleértve a szeptikus sokkot \\
\hline & 6. Intenzív osztályos ellátást igénylő bármely szervi elégtelenség \\
\hline
\end{tabular}

*Súlyos vagy kritikus COVID-19-be való progressziót előrejelző kockázati tényezők

\begin{tabular}{ll}
\hline Általános kockázati tényezők & $\begin{array}{l}\text { 1. Életkor } \geq 65 \text { év } \\
\text { 2. Krónikus kardiovaszkuláris-, tüdő-, máj-, vese-, neurológiai betegségek, obesitas, diabetes } \\
\text { mellitus }\end{array}$ \\
& $\begin{array}{l}\text { 3. Immmunszupprimált állapotok*, beleértve a malignus hematológiai és onkológiai } \\
\text { betegeket is }\end{array}$ \\
\hline Citokinvihar biokémiai kockázati & $\begin{array}{l}\text { 1. Szérum IL- } 6 \geq 3 \mathrm{x} \text { felső normális értéknek } \\
\text { tényezői }\end{array}$ \\
$\begin{array}{ll}\text { 2. Szérum ferritin }>300 \mathrm{ug} / \mathrm{l} \text {, és } 24 \text { órán belül duplázódik } \\
\text { 3. Szérum ferritin }>600 \mathrm{ug} / \mathrm{l} \text {, és } \mathrm{LDH}>480 \mathrm{U} / \mathrm{l}\end{array}$ \\
4. Emelkedett szérum D-dimer $(>1000 \mathrm{ng} / \mathrm{l})$
\end{tabular}

*Congenitalis immundeficiencia, asplenia, nem kontrollált HIV-fertőzés, szolidszerv- vagy hemopoetikus őssejt-transzplantáció, kemoterápia vagy immunszuppresszív terápia 6 hónapon belül, szisztémás szteroidhasználat ( $\geq 20 \mathrm{mg} / \mathrm{nap}$ prednizolon ekvivalens szteroid használata $\geq 2$ héten át), autoimmun betegség, májcirrhosis, krónikus alkoholizmus 
korábbi vagy jelenleg is alkalmazott immunkemoterápiák és más gyógyszerek okozta expozíciók is okozhatnak mellkasi panaszokat vagy képalkotó eltéréseket, illetve lázat (drugfever). Ritkán hasi kórképek, pl. akut pancreatitis vagy akut cholangio-cholecystitis is okozhatnak mellkasi panaszokat. A hatékony differenciáldiagnosztikát az eddig felsorolt eljárásokon kívül az elektrokardiogram, az ágy melletti transthoracalis echocardiographia és az artériás vérgázanalízis támogatja.

\section{A COVID-19 súlyossági stratifikációja és prognózisának becslése}

\section{A COVID-19 súlyossági stratifikációja}

Az igazolt COVID-19 betegek WHO-ajánlás alapján felállítható súlyossági stratifikációját, az ehhez tartozó kritériumokat és járulékos rizikófaktorokat a 3. táblázat szemlélteti. A súlyossági stratifikáció elengedhetetlen a diagnosztikus és terápiás tervezés, a beteg otthoni vagy kórházi elhelyezésének elbírálása és várható prognózis meghatározása szempontjából [10,11, 15].

Az enyhe stádiumba sorolható beteg szubjektív panaszok és objektív paraméterek alapján nem dyspnoés, nincs addicionális $\mathrm{O}_{2}$-igénye, és képalkotó vizsgálattal pneumonia jelenléte nem igazolható. Az otthoni megfigyelés vagy hospitalizáció kérdéséről a 4. táblázat alján szereplő rizikófaktorok meglétének értékelésével, a beteg együttmüködő-készségének és a szociális háttér felmérésével lehet dönteni. A középsúlyos stádiumú betegek diagnózisakor tachydyspnoésak, képalkotó felvételeken pneumoniájuk lehet, általában $\mathrm{O}_{2}$-terápiát igényelnek. Súlyos COVID19-ben a hypoxaemia uralja a klinikai képet: a betegek noninvazív módszerekkel egyre nehezebben oxigenizálhatóak, a mellkasi CT-n masszív tüdőérintettség mutatko- zik. Középsúlyos-súlyos betegek ápolása monitorizálási lehetôséggel felszerelt osztályon, szubintenzíven vagy „őrzőben” a legcélszerübb. A kritikus állapotú COVID-19 betegek légzési-keringési instabilitás, vagy más szervek elégtelensége miatt azonnali intenzív osztályos ellátást igényelnek $[10,11,15]$.

\section{A COVID-19 prognozisának becslésére szolgáló pontrendszerek}

A COVID-19 következtében elhunyt betegek általában 65 év feletti, dohányos férfiak, 50-70\%-uk a 4. táblázatban ismertetett, legalább egy krónikus betegségben szenvedett. A halál oka leggyakrabban ARDS okozta refrakter hypoxaemia, szívinfarktus vagy szívmegállás volt $[1,10$, 11, 16-23]. A kórházban kezelt COVID-19 klinikai progressziójának valószínüségét a $C A L L$ score alapján becsülhetjük. Ez az életkor, abszolút lymphocytaszám, LDH és komorbiditás meglétének kategorizált értékeihez rendelt pontszámok összegeként számítható: 4-6 pont között $10 \%, 7-9$ pont esetén $10-40 \%, 10-13$ pontnál $50 \%$ feletti a progresszió valószínüsége [21]. A COVID-GRAM score a kórházi ellátás során kritikus állapotig történő progreszszió előrejelzésére szolgál. Tíz tényezőt vesz figyelembe (életkor, kóros mellkasi képalkotó, hemoptysis, dyspnoe, eszméletlenség, komorbiditások száma, malignus betegség az anamnézisben, neutrophil/lymphocyta arány, $\mathrm{LDH}$, direkt bilirubin), és a progresszió valószínűségét három fokozatú kategorikus skálán adja meg [17]. A víruspneumonitisek 90 napos mortalitásának becslésére létrehozott MULBSTA score a multilobaris infiltrátum meglétét, a lymphopeniát, a bakteriális koinfekciót, a dohányzási státuszt, a hipertóniát és a 60 év feletti életkort veszi figyelembe [19]. A klinikai pontrendszerek használata elősegítheti a súlyos prognózisú betegek korai felismerését, de nem helyettesítheti a klinikai gondolkodást,

4. táblázat. A COVID-19 egy lehetséges rizikóadaptált kezelési stratégiája az elérhető evidenciák alapján

Antivirális terápia: súlyosság szerint

Enyhe + rizikófaktor*: FVP, ennek hiányában $\mathrm{CQ}^{* *}$ vagy $\mathrm{HCQ} \pm \mathrm{AZI}^{* *}$

Középsúlyos: FVP vagy RDV, ezek hiányában CQ vagy $\mathrm{HCQ} \pm \mathrm{AZI}$ vagy $\mathrm{LPV} / \mathrm{r}$

Súlyos: RDV, ezek hiányában $\mathrm{CQ}^{* *}$ vagy $\mathrm{HCQ} \pm \mathrm{AZI}^{* *}$ vagy $\mathrm{LPV} / \mathrm{r}$

Kritikus: RDV, ennek hiányában CQ vagy $\mathrm{HCQ} \pm \mathrm{AZI}$

Immunmoduláció (hiperinflammáció gátlása): bármilyen súlyosság esetén

Citokinvihar biokémiai kockázati tényezői ${ }^{*}$ esetén: tocilizumab \pm ruxolitinib

Perzisztálóan PCR-pozitiv, kritikus állapotú lélegeztetett beteg: rekonvaleszcens plazma

Hypogammablobulinemiás, kritikus állapotú lélegeztetett beteg: IVIG

ARDS esetén (kiegészitésként): dexametazon vagy metilprednizolon

\footnotetext{
AZI: azithromycin, CQ: chloroquin, FVP: favipiravir, HCQ: hidroxychloroquin, IVIG:

intravénás immunglobulin, LPV/r: lopinavir/ritonavir, RDV: remdesivir.

* Ld. a 4. táblázatot.

** A cardiotoxicitás lehetőségének mérlegelését követően!
} 
mivel az alapjukat adó modellek reprodukálhatósága kérdéses, széles körü külső validációjukra pedig még nem került sor [20].

\section{A COVID-19 gyógyszeres kezelési stratégiái}

\section{Jogi és etikai megfontolások}

A COVID-19 kezelésére randomizált-kontrollált vizsgálattal igazolt, egyértelműen hatékony és biztonságos, törzskönyvezett gyógyszerrel nem rendelkezünk, így minden, ebben a kórképben alkalmazott terápia experimentális, off-label jellegü. Így, amikor csak lehetőség nyílik rá, a szerek alkalmazása klinikai vizsgálat keretén belül javasolt. A betegeket etikai kötelességünk tájékoztatni a gyógyszerek esetleges hatástalanságáról, és azok eddig megismert potenciális mellékhatásairól. A következő bekezdésekben felsorakoztatott stratégiák in vitro adatokon, állatmodellek eredményein, klinikai megfigyeléseken és kis betegszámú intervencionális vizsgálatokon, valamint az elérhető nemzetközi ajánlások szakmai konszenzusain alapulnak. A téma iránt érdeklődőknek a szerzők a National Institutes of Health (NIH, www.covid19treat mentguidelines.nih.gov), valamint az Infectious Diseases Society of America (IDSA, www.idsociety.org/practiceguideline) gyakran frissülő honlapjait ajánlják [24, 25].

A WHO 2020. március 18-án bejelentette az ún. Solidarity Trial indulását. Utóbbi egy nemzetközi, III-IV. fázisú klinikai vizsgálat, melynek célja súlyos COVID-19 miatt hospitalizált betegek bevonásával négy eltérő terápiás lehetőség hatékonyságának és biztonságosságának tesztelése. A négy kar: remdesivir, lopinavir/ritonavir, lopinavir/ ritonavir + IFN $\beta$-1a, és chloroquin/hydroxychloroquin. A vizsgálat, melyhez eddig több, mint száz ország csatlakozott, mindeddig az egyik legnagyobb szabású antiinfektív kutatási projekt [26]. Más nemzetközi klinikai vizsgálatokról a www.covid-trials.org, a www.who.int/ ictrp és a www.clinicaltrials.gov oldalakon kaphatunk információkat.

Ahogy azt az első közleményben olvashattuk, a COVID-19 kezelésének két alapvető iránya a vírus intracelluláris ciklusának gátlása (antivirális gyógyszerek), másrészt a következményes immundiszreguláció befolyásolása (immunmoduláns gyógyszerek). A 67/2020. (III. 26.) Kormányrendelet alapján a hazai betegellátásban indikáción túli gyógyszeralkalmazást igénylő egyes meghatározott COVID-19 terápiák megkezdéséhez a Kormányrendelet 3 . $\$(2)$ bekezdése értelmében az Országos Gyógyszerészeti és Élelmezés-egészségügyi Intézet (OGYÉI) engedélyének előzetes kérelmezése és kiadása nem szükséges. A jogszabály az alábbi hatóanyagokra vonatkozik: hydroxychloroquin, chloroquin, remdesivir, lopinavir, ritonavir, ruxolitinib, azithromycin, oseltamivir, tocilizumab, favipiravir, infliximab, adalimumab, baricitinib, canakinumab, intravénás immunglobulinok, sarilumab, siltuximab, sofosbuvir, interferon-alfa.
A Kormányrendelet $3 . \$$ (3) bekezdése értelmében, a fenti esetekben az indikáción túli gyógyszeralkalmazásról utólagos bejelentést kell tenni az OGYÉI részére, legkésőbb a veszélyhelyzet megszünésétől számított 90 napon belül [27].

\section{A COVID-19 antivirális gyógyszerei}

A COVID-19 egy lehetséges rizikóadaptált kezelési stratégiáját az 4. táblázat szemlélteti. A táblázat a nemzetközi stratégiák mellett saját centrumunk lehetőségeit is tükrözi. A gyógyszerek egy része bizonyos országokban korábban más indikációkban már forgalomban volt, és ezt követően került kipróbálásra COVID-19-ben. Ugyanakkor más készítmények viszonylag új fejlesztés eredményei [28].

A chloroquin (CQ) és a hydroxychloroquin (HCQ) (utóbbi valószínüleg hatékonyabb) a virális exo- és endocytosis inhibícióján keresztül in vitro gátolják a SARSCoV-2-t [29]. Feltételezett hatékonyságukat erre, valamint bizonyos immunreumatológiai kórképek (SLE, RA) kezelésében kihasznált gyenge antiinflammatorikus tulajdonságukra alapozták, a klinikai vizsgálatok eredményei azonban ellentmondásosak. A CQ-t egy korai, bizonytalan módszertannal készült kínai tanulmány sikeresnek találta a COVID-19 terápiájában [30]. Egy másik, kis betegszámú, nem-randomizált francia vizsgálat a SARS-CoV-2 eliminációját gyorsabbnak találta azokban a betegekben, akik HCQ-t kaptak, kiváltképp, ha azt azithromycinnel (AZI) kombinálták. A vizsgálat azonban vitatható módszertana miatt heves kritikákat kapott [31, 32]. Enyhe és középsúlyos COVID-19 betegek körében elvégzett kínai randomizált vizsgálat a HCQ alkalmazása során a kontrollhoz képest nem talált szignifikáns különbséget a 28 napos PCR-negativitás elérése vagy klinikai gyógyulás tekintetében. Az intervenciós ágon ellenben több nem kívánt esemény jelentkezett [33]. Az eddigi egyik legnagyobb betegszámú, USA-ban folytatott, retrospektív vizsgálat az intubáció vagy halál kompozit végpont vonatkozásában nem talált szignifikáns különbséget a HCQ-nal kezelt betegek és a kontrollcsoport között [34]. Egy másik amerikai vizsgálat sem a $H C Q$, sem pedig a $H C Q+A Z I$ csoportban nem tudta igazolni a gyógyszer(ek) kórházi halálozást csökkentő hatását [35]. A CQ/HCQ a korrigált QT-idő (QTc) megnyúlását okozó szerek, ezt a hatást az AZI potencírozhatja. A $500 \mathrm{msec}$ feletti QTc a CQ/HCQ terápiát ellenjavallja, a már bevezetett terápia alatt pedig a felfüggesztés abszolút indikációja. Egy, a CQ-nal végzett dóziskereső klinikai vizsgálatot idő előtt meg kellett szakítani, mivel a magasabb dózist kapó betegek ágán a halálozás megnövekedett [10]. Az eddigi legnagyobb, regiszter alapú vizsgálat sem a CQ sem a HCQ alkalmazása kapcsán nem tudott előnyt igazolni (makroliddal vagy anélkül) a hospitalizált COVID-19 betegek klinikai kimenetelére vonatkozóan, ellenben a gyógyszereket kapók körében a végzetes kamrai tachycardiák magasabb gyakoriságát rögzítették [36]. Az eddigi adatok alapján a Solida- 
rity Trial szervezői a CQ/HCQ kart átmenetileg felfüggesztették interimelemzés céljából [26]. Egyes szerzők a CQ/HCQ bizonytalan hatékonyságának hátterében felvetették, hogy betegek a fertőzésük túl késői szakaszában, valamint a gátló hatás kifejlődéséhez szükségesnél alacsonyabb dózisban kapták a gyógyszert [37, 38].

A lopinavir/ritonavir (LPV/r) HIV1-proteázinhibítor kombináció alkalmazhatósága előzetes, a SARS-CoV-1gyel szerzett in vitro és in vivo tapasztalatok alapján merült fel. A célpont a SARS-CoV-2 hasonló enzimének gátlása lett volna, azonban az eddigi legnagyobb, súlyos COVID-19-ben végzett randomizált-kontrollált vizsgálat nem talált szignifikáns klinikai javulást a kontrollcsoporthoz képest. Lehetséges azonban, hogy a lopinavir/ritonavir hatékonysága IFN $\beta$-1b és ribavirin korai adásával fokozható enyhe-középsúlyos COVID-19 betegekben. A LPV/r mellékhatásai közül a gasztrointesztinális motilitászavart (hányás, hasmenés), hepatotoxicitást és acut pancreatitist szükséges kiemelni. A CQ/HCQ-hoz hasonlóan a LPV/r elégtelen hatékonyságát a túl késői adagolás, és a gyógyszerkombináció kedvezőtlen farmakokinetikája legalábbis részben magyarázhatja [39-41]. In vitro modellek alapján a szintén HIV1-proteázinhibítor darunavir használata is felmerült, a gyógyszerrel szerzett klinikai tapasztalat azonban szegényes. A ribavirin monoterápiában történő alkalmazásának gátat szab az in vivo hatékonyság eléréséhez szükséges igen nagy dózis, valamint a vegyület dózisdependens hemato- és hepatotoxicitása [32].

A remdesivir SARS-CoV-2 elleni hatékonyságát in vitro és állakísérletekben is igazolták. Az egyik korai, kontrollcsoport nélküli esetsorozat-vizsgálatban az oxigénfüggőség csökkenését figyelték a remdesivirt kapó súlyos COVID-19 betegek körében. Egy nemrég publikált, súlyos COVID-19-ben szenvedők körében végzett randomizált-kontrollált vizsgálatban viszont a remdesivir használata nem járt statisztikailag szignifikáns klinikai előnnyel. Ennek kapcsán felmerült, hogy, akik korábban részesültek a gyógyszeres terápiában, hamarabb mutattak klinikai javulást a kontrollokhoz képest. A vizsgálatot lassú betegtoborzás miatt a tervezettnél hamarább abba kellett hagyni [42]. Jelenleg is folynak randomizált-kontrollált vizsgálatok enyhe-középsúlyos és súlyos állapotú COVID19 betegek körében. Az interimanalízis alapján úgy tünik, hogy a remdesivir a klinikai javulásig eltelt időt szignifikánsan, a kórházi halálozást trendszerűen csökkentheti. A szer alkalmazását gasztrointesztinális és hepatotixikus mellékhatások kísérhetik [32, 43, 44].

A Japánban szezonális influenza kezelésére törzskönyvezett, azonban in vitro, állatkísérletek és humán vizsgálatok alapján más RNS-vírusok gátlására is alkalmas favipiravir használata felmerült COVID-19-ben is. Egy prospektív randomizált vizsgálatban, nem súlyos SARS-CoV-2 fertőzöttek körében, a komparátor umifenovirhoz képest a 7 napos gyógyulási ráta magasabb volt. Egy másik, nem-randomizált vizsgálat ugyanilyen súlyosságú betegek körében a PCR-negativitás gyorsabb bekövetkeztét és gyakoribb radiológiai regressziót talált a lopinavir/ritonavir kombinációhoz viszonyítva [32].

A camostat és a nafamostat szerin-proteáz inhibítorok (az előbbi Japánban törzskönyvezett acut pancreatitis kezelésére). Korai in vitro vizsgálatok kimutatták, hogy ezek a vegyületek a SARS-CoV-2 primingjáért felelős TMPRSS2 potens gátlószerei, így nem kizárt, hogy a fertőzés terápiájára is alkalmasak lehetnek. Az ezzel kapcsolatos klinikai vizsgálatok folyamatban vannak. Az oseltamivir értékelhető SARS-CoV-2-ellenes hatékonysággal nem bír [32, 45].

\section{A COVID-19 immunmoduláns gyógyszerei}

Amennyiben az antivirális terápiák túl későn, nem megfelelő dózisban kerülnek bevezetésre vagy ineffektívnek bizonyulnak, a kialakuló citokinvihar gátlására monoklonális antitest-, tirozinkináz-gátló-, kortikoszteroid- és plazmaterápiák jönnek szóba. Több centrumban klinikai kipróbálás alatt áll a mesenchymalis őssejtekkel (mesenchymal stem cell, $M S C$ ), valamint a vírusspecifikus T-sejtekkel végzett sejtterápia is.

A tocilizumab az IL-6-receptor elleni humanizált monoklonális antitest, melynek használatát rheumatoid arthritis, óriássejtes arteritis és CRS kezelésére korábban engedélyezték. A vegyület súlyos és kritikus állapotú COVID-19 betegek körében történő alkalmazhatóságát egy kínai, kis betegszámú esetsorozat kapcsán vetették fel: a gyógyszer képes lehet a hiperinflammációs fázist fékezni, különösképpen, ha kétoldali multiplex tüdőgócok jelenléte és magas szérum IL-6-szint is kimutatható. $\mathrm{Az}$ azóta Franciaországban elindult randomizált klinikai vizsgálat interimanalízise a fenti feltételezést alátámasztani látszik, de a vizsgálat eredményeit közreadó közlemény még nem jelent meg [24, 46]. Hazánkban elsőként centrumunkban alkalmaztunk infektológiai osztályon tocilizumabot [47]. Egy másik IL-6 receptorantagonistával, a rheumatoid arthritisben törzskönyvezett sarilumabbal is megkezdődött egy II-III. fázisú klinikai vizsgálat súlyos és kritikus állapotú COVID-19 betegek bevonásával. Az interimanalízis eredményei szerint az alacsonyabb dózissal kezelt betegek körében a halálozás trendszerűen magasabb volt, mint a magas dózisú, illetve a placebo karon. Emellett valószínű, hogy a gyógyszer több klinikai előnynyel jár a kritikus, mint a súlyos állapotú COVID-19 betegek körében [24, 32]. A siltuximab rekombináns humán-egér kiméra monoklonális antitest, mely az IL-6-ot célozza. Jelenleg multicentrikus Castleman-betegségben törzskönyvezett, és előzetes klinikai adatok alapján lehetséges, hogy COVID-19 terápiájában is hasznosítható lehet. A randomizált klinikai vizsgálatok jelenleg is zajlanak. A felsorolt három IL-antagonista használatát illetően evidencia alapú állásfoglalás nem fogalmazható meg [24, 28]. Az eculizumab az 5. komplementkomponenst (C5) célzó humanizált monoklonális antitest, mely a komplementkaszkád fiziológiás vagy patológiás aktivációja során megakadályozza a molekula C5a anafilatoxinra és C5b 
membránattack-komplex összeállását toborzó peptidre történő hasítását. Feltételezések szerint az eculizumab a COVID-19 során tapasztalt kóros komplementaktivitást blokkolhatja, ezzel kivédve az endothelsérülést és a célszervek sejtjeinek károsodását. A klinikai kipróbálás egyelöre folyamatban van [24].

A tirozinkinázgátlók közül a ruxolitinib és baricitinib a JAK-kináz-, míg az ibrutinib a Bruton-tirozinkináz(BTK-) downstream proinflammatorikus útvonalát gátolja. Nem kizárt, hogy a korábbról, pl. krónikus lymphoid leukaemia miatt BTK-inhibítort szedő betegek körében a gyógyszer relatív védelmet jelent a fertőzés negatív kimenetelei ellen. Bár bizonyos korai eredmények a középsúlyos és súlyos COVID-19-ben felvetik alkalmazhatóságukat, adásuk hosszú távú biztonságosságára vonatkozó egyértelmű adatok még nem állnak rendelkezésre $[11,24$, 48-50].

A szisztémás kortikoszteroidok adása az ARDS-ben szenvedő betegek csoportját kivéve ellenjavallt, mivel klinikai előnyük nem igazolt, viszont a vírusürülést elnyújtják, és másodlagos fertőzésekre hajlamosíthatnak. ARDS-ben rövid távú, alacsony dózisú dexametazon vagy metilprednizolon, presszorrefrakter szeptikus sokkban hidrokortizon adása megkísérelhető. Azon COVID-19betegek körében, akik valamely alapbetegségük miatt tartósan szteroidot használnak, a gyógyszer prompt elhagyása nem javasolt, de a dózis csökkentése megkísérlendő. A korábban, más indikációval megkezdett inhalációs kortikoszteroidok folytathatóak, azonban ezeket COVID-19 indikációjával elkezdeni nem indokolt [24, 28, 43].

$\mathrm{Az}$ intravénás immunglobulin (IVIG) az egyik legbiztonságosabb immunmoduláns és szubsztitúciós terápiának tekinthető bizonyos, életet veszélyeztető infekciók kezelésében, különösképpen a humorális immunitás zavara esetén. Az elképzelés alapján az IVIG aspecifikus immunszuppresszív hatással képes fékezni a betegséghez kapcsolódó kóros immunaktivációt. A korai esetbeszámolók biztatóak, főleg azokban a középsúlyos és súlyos állapotú COVID-19-fertőzöttekben, akik az első 2-3 napban kapták az IVIG-et. Azonban a forgalomban lévő IVIG-készítmények COVID-19-ben való alkalmazásának előnyét randomizált-kontrollált vizsgálatban még nem erősítették meg, a háttérimmunitás hiánya miatt SARSCoV-2-ellenes aktivitásuk aligha lehet magas, és a korábban ismertetett $\mathrm{ADE}$ jelenségének teoretikus veszélye így is fennállhat [24, 43, 46, 51]. Az IVIG adásával kapcsolatos problémákat kiválthatja a rekonvaleszcens plazma adása [32]. Az elképzelés szerint a rekonvaleszcens plazmában található specifikus ellenanyag-tartalom passzív immunizációként hat, vagyis hatékonyan meggátolja a viremiát, az újabb sejtek fertőződését, és elősegíti a már inficiált sejtek ürülését [43]. Az első kínai, nem kontrollált esetbeszámolók alapján a plazmaterápia jól tolerálható, és a beadástól számított 2-3 nap alatt klinikai regresszió jelei mutatkoztak. Ezzel párhuzamosan 7-10 nap alatt általában a radiomorfológia is javulást mutatott [52]. Egy összefoglaló tanulmány szerint a rekonvaleszcens plazma adása csökkentheti a mortalitást, bár ezt randominzált-kontrollált adatok még nem támasztják alá [53]. A betegséget átvészelt betegek véréből plazmapheresissel kivont készítményt valószínüleg a perzisztálóan PCR-pozitív, kritikus állapotú, lélegeztetett COVID-19-betegekben javasolt alkalmazni, a felvételtől/diagnózistól számítva minél korábban. Kérdéses azonban, hogy mely további betegcsoportok profitálhatnak a plazmaterápiából, illetve a donációt milyen feltételekhez (pl. mennyi az optimális neutralizáló antitesttiter) érdemes vagy szükséges kötni [24]. Hazánkban a plazmaterápiát elsőként alkalmaztuk centrumunkban, és a terápia már a Semmelweis Egyetemen is elérhető $[54,55]$.

$\mathrm{Az}$ immunmoduláns terápia celluláris ágát az MSCterápia jelenti. Több in vivo állati és ex vivo humán tüdőmodellen végzett kísérlet tanulsága alapján ezek az őssejtek pleiotróp hatásúak: regeneratív aktivitásuk mellett részt vesznek az anti-inflammatorikus immunregulációban, az angiogenezis fokozásában és a fibrosis gátlásában, az intraalveolaris folyadékreszorpcióban, fájdalomcsillapításban, és az alsó légutak patogénürítésében is. $\mathrm{Az}$ MSC-k lokális és intravénás beadásának biztonságosságát és hatékonyságát több korábbi humán klinikai vizsgálat is alátámasztotta, így nem kizárt, hogy a terápia csökkenthetné a COVID-19 mortalitását és késői morbiditási terhét [56-59]. Viszonylag újabb eredmény, hogy sikerült rekonvaleszcens donorokból ex vivo vírusreaktív IFN+ T-sejteket kivonni a klinikai terápiás gyakorlatban is használható koncentrációban [60].

Mint az részben már említésre került, a szerzők munkahelyén kiterjedt klinikai kutatások folynak a COVID-19 antivirális és immunmoduláns kezelési módozataival. Ezek ugyan még az adatgyüjtés fázisában vannak, de több terápiás ág alkalmazása ígéretesnek tünik.

\section{A COVID-19 kiegészitö antimikrobiális terápiái}

Az elérhető irodalmi adatok alapján felállított, saját centrumunkban is alkalmazott kiegészítő antimikrobiális terápiákat a 5. táblázat szemlélteti. A szerzők kifejezett javaslata a kollégák számára, hogy a COVID-19-betegek ellátásában mindig vonjanak be infektológus szakorvost is.

A korábban említettek értelmében, kritikus állapotú COVID-19-betegek körében a legnagyobb a szekunder bakteriális infekciók kialakulásának kockázata. Így az intenzív osztályos ellátás kapcsán a nyitó mikrobiológiai vizsgálatok (ld. korábban) levételét követően empirikus antibakteriális terápia indítandó. $\mathrm{Az}$ empirikus terápia megkezdését illetően a beteg klinikai állapota az elsődleges szempont. Biomarker alapú (pl. procalcitonin vezérelte) validált és biztonságos algoritmus jelenleg nem áll rendelkezésre. Az empirikus antibakteriális terápiának céloznia kell a legvalószínübb bakteriális kórokozókat. A nem súlyos állapotú COVID-19 betegek esetében alsó légúti bakterális infekció fellépte valószerűtlen a klinikai stádium progressziójának hiányában, így korai empirikus 
5. táblázat. A COVID-19-hez csatlakozó rizikóadaptált empirikus antimikrobiális stratégia centrumunkban az elérhető evidenciák alapján

\begin{tabular}{|c|c|c|}
\hline \multirow{2}{*}{ Súlyosság } & \multicolumn{2}{|c|}{ Immunszupprimált állapot vagy súlyos társbetegség } \\
\hline & NEM ÁLL FENN & FENNÁLL \\
\hline \multirow{3}{*}{ Enyhe } & Rizikófaktor nincs: nem szükséges & \\
\hline & Rizikófaktor van: amoxicillin vagy ceftriaxon & - \\
\hline & \pm doxycyclin/azithromycin ${ }^{*, *}$ & Ceftriaxon + doxycyclin/azithromycin ${ }^{*, \#}$ \\
\hline Középsúlyos & \multirow{2}{*}{ Ceftriaxon + doxycyclin/azithromycin* } & (Piperacillin/tazobactam vagy cefepim vagy ceftazidim) \\
\hline Súlyos & & + doxycyclin/azithromycin ${ }^{*, \#}$ \\
\hline
\end{tabular}

\begin{tabular}{ll} 
& Piperacillin/tazobactam vagy cefepim \\
Kritikus & ÉS levofloxacin ${ }^{*}$ \\
& ÉS vancomycin vagy linezolid \\
\hline
\end{tabular}

Invazív MRSA-fertőzésre rizikó esetén: bármelyik fenti stratégia mellé vancomycin vagy linezolid

P. jirovecii rizikó esetén (COVID-19-tôl függetlenül): bármelyik fenti stratégia mellé co-trimoxazol

Profilaktikus/preemptív antifungalis stratégia: kritikus állapotú beteg esetén echinocandin (caspofungin, anidulafungin, micafungin)

* Amennyiben az antivirális stratégia azithromycint is tartalmaz, külön doxycyclin indítása nem indikált.

${ }^{*}$ CAVE: QT-megnyúlás!

antibiotikum indítása nem indokolt. Perzisztáló láz, klinikai progresszió vagy instabilitás, bakteriális infekcióra gyanús CT-kép esetén azonban korai empirikus antibiotikum indítása megfontolandó. COVID-19 indikációjával profilaktikus antibiotikumadásnak nincs helye [12, 13, 61].

Mivel a COVID-19 járvány a Föld északi féltekén kezdetben egybeesett a szezonális influenzáéval, más centrumokhoz hasonlóan a középsúlyos-súlyos, valamint kritikus állapotú betegekben, illetve a kétoldali radiológiai eltérést mutató személyekben empirikusan terápiás dózisú oseltamivir adására is sor került, amíg az influenzavírus jelenlétét PCR-vizsgálat ki nem zárta. Míg nem kritikus állapotú COVID-19-betegek körében az invazív gombainfekciók rizikója valószínúleg nem magasabb, kritikus állapotú betegek esetében a fellépő invazív tüdőaspergillosis, valamint candidaemia kockázata nem elhanyagolható, így körükben profilaktikus/preemptív antifungális stratégia választhatónak tünik (különösképpen, ha invazív gombainfekcióra hajlamosító egyéb rizikófaktorokkal is rendelkeznek) [12, 13, 61].

$\mathrm{Az}$ empirikusan megkezdett antimikrobiális terápiák során a stewardship elveknek megfelelően érdemes a lehető legkoraibb deeszkalációra törekedni. Az antibakteriális és antifungális terápiák deeszkalációját a tartós klinikai stabilitás elérése, a releváns mikrobiológiai leletek értékelése és a csökkenő biomarker-tendencia valószínűleg vezérelheti. A láz nyomon követése és a sorozatosan végzett mellkasi képalkotók eredménye ugyanerre a célra nem tünik alkalmasnak $[12,13,61]$.

\section{A COVID-19 antikoaguláns profilaxisa és terápiája}

A COVID-19-asszociált coagulopathia felismerése és ellátása valószínúleg jobb kimenetellel társul hospitalizált betegekben, emiatt az International Society on Thrombosis and Haemostasis és az American Society of Hematology elérhető szakmai ajánlásai profilaktikus és terápiás dózisú antikoagulálás bevezetését javasolja a klasszikus alvadási idők (INR, APTI, TI) mellett a fibrinogén és D-dimer akár napi rendszerességủ monitorizálása mellett [62, 63].

Amennyiben a nem kritikus állapotú COVID-19 beteg diagnózisakor zajló thrombemboliára nincs klinikai gyanú, profilaktikus antikoagulálás bevezetése javasolt alacsony mólsúlyú heparin (low molecular weight heparin, LMWH) adásával, ha ennek abszolút kontraindikációja nem áll fenn (aktív vérzés az elmúlt 24-48 órában vagy thrombocytaszám $<25 \times 10^{9} / 1$ ). Azok a súlyos vagy kritikus állapotú COVID-19 betegek, akiknél progrediáló D-dimer-szint, jelentős szisztémás gyulladást és sokszervi diszfunkciót dokumentálunk, feltehetően profitálhatnak a terápiás dózisú LMWH-terápia bevezetéséből, ha azt a vérzési rizikó nem kontraindikálja. Nem ismert, hogy a COVID-19-et átvészeltekben a kórházból történő távozást követően meddig van szükség a thromboprofilaxis fenntartására [62, 63].

A kórházi felvételre nem kerülő COVID-19 betegek körében nem szükséges rutinszerűen antikoagulálás, hacsak más rizikófaktorok megléte miatt az nem indikált. Az orális antikoagulánsok (K-vitamin antagonisták, direkt 
ható antikoagulánsok) szerepe a COVID-19 antithrombotikus kezelésében nem egyértelmü. A COVID-19 fertőzés előtt, más indikációk miatt megkezdett aggregációgátló és antithrombotikus terápiák folytatandók a betegség alatt is [64-66].

\section{COVID-19 a hematológiai osztályon? - betegek és stratégiák}

\section{Hogyan tudjuk megvédeni betegeinket?}

Az Emberi Erőforrások Minisztériuma (EMMI) Egészségügyi Szakmai Kollégiumának Hematológiai és Transzfuziológiai Tagozata megfogalmazta azokat az iránymutatásokat, melyek alapján a hematológiai osztályokon a járóés fekvőbeteg-ellátás biztonságosabbá tehető [67]. A következő bekezdésekben bemutatjuk centrumunk jelenlegi gyakorlatát is.

A járóbeteg-ellátás online és telefonos alapúvá alakítása megakadályozhatja a rendelésre érkezett betegek kis területen való összetömörülését. A hazánkban működő, felhő alapú virtuális egészségügyi tér elősegítheti a betegellátás ilyen irányú áramvonalasítását $[68,69]$. Ha a beteg ellátása során COVID-19-re gyanús epidemiológia adatra vagy klinikai tünetre derül fény, a hematológiai alapbetegségtől függetlenül a hatályos NNK-eljárásrend alapján kell cselekednünk: SARS-CoV-2 irányba PCR vizsgálatot kell kezdeményezni. Pozitivitás esetén a beteget klinikai állapotától függően otthonában vagy az erre kijelölt osztályon kell izolálni. Mivel láttuk, hogy a hematológiai betegeket - fertőződésük esetén - súlyosabb kimenetel fenyegeti, így minden eset egyéni elbírálására kifejezett figyelmet kell fordítani [67, 70-72].

Amennyiben a beteg osztályos felvétele szükségessé válik, pl. diagnosztika vagy kezelés céljából, az IDSA ajánlás értelmében, expozíciós anamnézistől és tünettantól függetlenül a beteget PCR-technikával szürni szükséges. Felvétel szempontjából különösen rizikósak azok a betegek, akik olyan intézményből kerülnek átvételre, ahol nozokomiális járvány feltételezhető vagy igazolt. A korábban ismertetettek miatt (legalább 48 óra különbséggel) minimum két PCR levétele indokolt. A tesztelési idő alatt a beteget az erre kijelölt részleg kórtermében izoláljuk és megfigyeljük. Az izoláció időtartamát a medián lappangási időhöz érdemes illeszteni (pl. felvételtől számított legalább 5 napig). Amennyiben a megfigyelési időszak alatt a beteg tartósan tünetmentes marad, és PCR-vizsgálatai negatívak, a hematológiai ellátás megkezdődhet. A megfigyelési időszak alatt a beteg potenciálisan fertőzöttnek tekintendő, így számára dedikált ellátó személyzetet kell kijelölni, és biztosítani szükséges az előírt egyéni védőfelszereléseket is. A fertőzés terjedése szempontjából a nem átgondolt betegutak és áthelyezések is veszélyforrást jelentenek [25, 67, 70-72].

A malignus hematológiai betegségben szenvedők jellemzően folyamatos orvosi kontrollt igényelnek vagy tar- tósan hospitalizáltak. Nincs arra vonatkozó egyértelmű bizonyíték, hogy körükben a pandémiát megelőzően kifejlesztett, evidencia alapú terápiás protokollokat a fertőzés potenciális veszélye miatt alapvetően szükséges volna megváltoztatni. Általánosságban az indukciós és egyéb, nem halasztható kezeléseket (pl. akut leukaemiák, agreszszív non-Hodgkin-lymphomák, célszervkárosodással vagy onkohematológiai urgenciával járó állapotok stb. esetén) meg kell adni. Szintén nem indokolt a komplett remisszióban lévő, őssejt-transzplantációra alkalmas betegek beavatkozásának halasztása, amennyiben a relapszus rizikója magas. Ezzel szemben az indolens lefolyású malignitásban szenvedők esetében a watch and wait stratégiája választható, a fenntartó kezelések szükség és lehetőség szerint halaszthatóak, vagy törekedni lehet ambuláns és kúraszerű ellátás keretei közötti megadásukra. Amikor a malignus betegség biológiai viselkedése engedi, vagy a kuratív célú kezelés nem lehetséges, érdemes meggondolni orális kemoterapia és kevésbé intenzív protokollok előtérbe helyezését is. Az őssejt-transzplantációra érkező betegek felvételkor a fenti séma szerint szürendők, és pozitivitás esetén a transzplantációt a tünetmentesség elérésétől számított két negatív PCR eredményéig (de minimum 14 napig) halasztani szükséges. Pozitív donor a fertőzése lezajlását követően minimum 28 napig nem adhat őssejteket. A részletek az European Society for Blood and Marrow Transplantation honlapján olvashatóak (www.ebmt.org/ covid-19-and-bmt) [72-80].

\section{Hogyan tudjuk megvédeni saját magunkat?}

Járványügyi vagy klinikai szempontból gyanús beteg vizsgálata, ellátása során az egyéni védőfelszerelések szabályos használata, valamint a kézmosás-bőrfertőtlenítés minden egészségügyi dolgozó számára javasolt. Az egyéni védőfelszerelés része többek között az egyszer használatos zsilipruha, az arra húzandó külső, vízhatlan borítású köpeny vagy a teljes testet elfedő kapucnis overáll, a gumis mütőssapka, egyszer használatos gumikesztyük, az orrot és szájat jól fedő maszkok, a védőszemüveg vagy az egész arcot takaró plexi arcpajzs, lábzsák vagy lábszárvédő. $\mathrm{Az}$ egyéni védőfelszerelések helyes felvételéről (donning) és levételéről (doffing) a hatályos eljárásrendben, valamint az EMMI Egészségügyi Szakmai Kollégiumának Aneszteziológiai és Intenzív Terápiás Tagozata által kiadott ajánlásban olvashatunk bővebben (utóbbiban képekkel illusztrálva) [81].

$\mathrm{Az}$ egyéni védekezés általánosabb eszközei minden egészségügyi ellátó számára elérhetőek és erősen javasoltak: hordjunk sebészi vagy pamutból készült maszkot, végezzünk gyakran (legalább) higiénés kézmosást, és tartsuk be a távolságtartásra (social distancing) vonatkozó járványügyi javaslatokat. Amennyiben betegnek érezzük magunkat, maradjunk otthon. Csökkentsük a fölösleges találkozások számát. A változó expozíciós kockázatnak kitett, tünetmentes egészségügyi személyzet tagjait a jelen epidemiológiai helyzetben valószínúleg nem indokolt ru- 
tinszerüen szürővizsgálattal ellenőrizni. Nem tisztázott, hogy pontosan kiket, milyen rendszerességgel vagy időintervallummal érdemes szürni, nem ismert az intervenció költséghatékonysága sem. Aszimptomatikus személyek egyszeri negatív teszteredményének prediktív értéke alacsony, ez hamis biztonságérzetet generálhat, és etikai aggályokat is felvethet. Az univerzális szürés valószínüsíthető előnye lehet a fölösleges karanténok hamarábbi feloldása, és az esetleges preszimptomatikus terjesztők időbeli izolálása [82, 83]. A tünetes vagy magát betegnek érző egészségügyi dolgozó tesztelése és mihamarábbi izolálása, a helyi járványok kapcsán vagy fertőzöttekkel létrejött kontaktust követően végzett légúti mintavétel természetesen javasolt és általánosan elfogadott stratégia [25, 78].

A COVID-19 ellen jelenleg bizonyítottan hatékony és biztonságos pre- és posztexpozíciós profilaxissal nem rendelkezünk. Preexpozíciós profilaxis gyanánt HCQ-val, posztexpozíciós profilaxisra rekonvaleszcens plazmával jelenleg is folynak klinikai vizsgálatok. A SARS-CoV-2 elleni, aktív immunizációt biztosító vakcinák fejlesztése is megkezdődött. Ezekben több biotechnológiai módszert és immunogén targetet is felhasználnak, a hatékony és biztonságos vakcina széles körü elérhetőségére azonban még hónapokat vagy annál is hosszabb időt kell várnunk $[24,25,84]$.

\section{Összefoglalás}

\begin{abstract}
„Megértem én már eleget, ennél is zordabb teleket. De olyat eddig sohasem, hogy vége egyszer ne legyen.”
\end{abstract}

Kányádi Sándor

A sorok írásakor Magyarországon a COVID-19 járvány lecsengő szakába került, az országos reprezentatív epidemiológiai tanulmány előzetes eredményei igen alacsony átfertőzöttségről tanúskodnak. Ennek ellenére a figyelem lankadása még korántsem indokolt. Bár a közösségi terjedést az egyéni védekezés lehetőségeivel, és a központi korlátozásokkal fékezni sikerült, sorra kerülnek azonosításra az ápolási otthonokra, valamint kórházakra lokalizált járványgócok. Egyelőre azt sem tudjuk, hogy a SARSCoV-2 „velünk marad-e”, vagyis a poszt-pandémiás időszakban szezonális vírusként keringeni fog, esetlegesen újabb epidémiákat kialakítva.

A COVID-19 jelentős betegségterhet ró az idős, komorbid betegpopulációkra, körükben a fertőzés okozta halálozás jelentős. Jelen összefoglalóból láthatjuk, hogy a korai, gyors diagnosztika alapját a labor- és képalkotó vizsgálatok gyakran típusos eltérései, valamint a légúti PCR adják. Ezzel, és a súlyossági kategória meghatározásával az adekvát terápia a lehető leghamarább megkezdendő, mely a negatív kimenetel esélyét csökkentheti. A COVID-19 beteget a fertőzés átvitelének megelözése céljából szigorúan izolálni szükséges, ilyen beteget ellátni csak egyéni védőfelszerelések alkalmazásával szabad.

A malignus hematológiai betegségekben szenvedő betegek SARS-CoV-2 fertőzés iránti veszélyeztettsége kifejezetten magas. A tünettan hasonló a hematológiai betegségekben nem szenvedőkéhez, azonban fertőzés esetén körükben súlyosabb lefolyásra, intenzív osztályos ellátási igényre és magasabb mortalitásra lehet számítani. A nozokomiális fertőzések elkerülése céljából egyénileg kell elbírálnunk minden osztályos felvételt. Amennyiben a beteget osztályon helyezzük el, egységes kórházi stratégia mentén iktassunk be kötelező PCR-alapú szüréseket és izolációt.

\section{Köszönetnyilvánítás}

A pandémia okozta károk enyhítése csapatmunka. A szerzők köszönetet mondanak centrumunkban hospitalizált COVID-19 betegek ellátásában részt vevő infektológus, gyermekgyógyász, neurológus, belgyógyász, intenzív terápiás specialista és mikrobiológus kollégáknak, valamint minden egészségügyi és egészségügyben dolgozónak áldozatkész munkájukért.

Nyilatkozat: A közlemény más folyóiratban korábban nem jelent meg, és máshová beküldésre nem került. A levelező szerző elolvasta a szerzői útmutatót.

Érdekeltségek: A szerzőknek a cikk megírásával és megjelenésével kapcsolatban nincsenek érdekeltségeik.

Anyagi támogatás: SZBG az EFOP-3.6.3-VEKOP-16-201700009 „Kiegészítő Kutatási Kiválósági Ösztöndíj”-ban és az Innovációs és Technológiai Minisztérium ÚNKP-19-3I-SE-74 kódszámú „Új Nemzeti Kiválóság Programjá”-nak szakmai támogatásában részesült. A közlemény megírása, illetve a kapcsolódó irodalmi kutatómunka közvetlen anyagi támogatásban nem részesült.

Szerzői munkamegosztás: Sz.B.G. - irodalomkutatás, a kézirat szövegezése, B.I., R.M., G.L., L.B., M.D., B.G., P.M., M.G., K.Z., Sz.J. és R.P. - a kézirat szövegezése, S.J. - a kézirat szövegezése, elkészültének szakmai felügyelete, V-N.I. - a kézirat szövegezése, a coronacentrum és a tudományos konzorcium vezetése.

A levelező szerző tisztelettel kéri a Szerkesztőséget és a Kiadót, hogy a téma prioritása, és a levelező szerző affiliációja alapján a közleményt online is elérhető Open Access formátumban szíveskedjenek megjelentetni publikációra való elfogadás esetén.

\section{Irodalom}

[1] Szabó B. In the middle of a new pandemic - what we know about COVID-19. [Egy új világjárvány közepén - amit eddig a COVID-19-ről tudni vélünk.] Orvostovábbképző Szemle. 2020. [Hungarian] 
[2] Sethuraman N, Jeremiah S, Ryo A. Interpreting Diagnostic Tests for SARS-CoV-2. JAMA. 2020. [epub, accessed: May 25, 2020]

[3] Kucirka L, Lauer S, Laeyendecker O, et al. Variation in false-negative rate of reverse transcriptase polymerase chain reaction-based SARS-CoV-2 tests by time since exposure. Ann Int Med. 2020. [epub, accessed: May 25, 2020]

[4] Vasarhelyi B, Kristof K, Ostorhazi E, et al. The diagnostic value of rapid anti IgM and IgG detecting tests in the identification of patients with SARS CoV-2 virus infection. [A specifikus IgM- és IgG-antitesteket detektáló gyorstesztek értéke a SARS CoV-2 vírusfertőzés kimutatásában.] Orv Hetil. 2020; 161(20): 807-812. [Hungarian]

[5] Yun H, Sun Z, Wu J, et al. Laboratory data analysis of novel coronavirus (COVID-19) screening in 2510 patients. Clin Chim Acta. 2020; 507: 94-97. [epub, accessed: May 25, 2020]

[6] Frater JL, Zini G, d'Onofrio G, et al. COVID-19 and the clinical hematology laboratory. Int J Lab Hematol. 2020. [epub, accessed: May 25, 2020]

[7] Thachil J, Tang N, Gando S, et al. Laboratory haemostasis monitoring in COVID-19. J Thromb Haemost. 2020. [epub, accessed: May 25, 2020]

[8] Gao L, Jiang D, Wen XS, et al. Prognostic value of NT-proBNP in patients with severe COVID-19. Respir Res. 2020; 21(1): 83-90.

[9] Kooraki S, Hosseiny M, Myers L, et al. Coronavirus (COVID-19) Outbreak: What the Department of Radiology Should Know. J Am Coll Radiol. 2020; 17(4): 447-451.

[10] Gandhi RT, Lynch JB, Del Rio C. Mild or Moderate Covid-19. N Engl J Med. 2020. [epub, accessed: May 25, 2020]

[11] Berlin DA, Gulick RM, Martinez FJ. Severe Covid-19. N Engl J Med. 2020. [epub, accessed: May 25, 2020]

[12] Bassetti M, Giacobbe DR, Aliberti S, et al. Balancing evidence and frontline experience in the early phases of the COVID-19 pandemic: current position of the Italian Society of Anti-infective Therapy (SITA) and the Italian Society of Pulmonology (SIP). Clin Microbiol Infect. 2020. [epub, accessed: May 25, 2020]

[13] Huttner BD, Catho G, Pano-Pardo JR, et al. COVID-19: don't neglect antimicrobial stewardship principles! Clin Microbiol Infect. 2020. [epub, accessed: May 25, 2020]

[14] Verweij PE, Gangneux J-P, Bassetti M, et al. Diagnosing COVID-19-associated pulmonary aspergillosis. The Lancet Microbe. 2020. [epub, accessed: May 25, 2020]

[15] WHO. Report of the WHO - China Joint Mission on Coronavirus Disease 2019 (COVID-19). 2020.

[16] Korsos A, Kupcsulik S, Lovas A, et al. Diagnostic consideration and bedside estimation of the prognosis in COVID-19 patients. [Diagnosztikus lépések és a betegség prognózisának becslése COVID-19-fertőzött betegeken ] Orv Hetil. 2020; 161(17): 667671. [epub, accessed: May 25, 2020] [Hungarian]

[17] Liang W, Liang H, Ou L, et al. Development and Validation of a Clinical Risk Score to Predict the Occurrence of Critical Illness in Hospitalized Patients With COVID-19. JAMA Intern Med. 2020. [epub, accessed: May 25, 2020]

[18] Auld S, Caridi-Scheible M, Blum JM, et al. ICU and ventilator mortality among critically ill adults with COVID-19. medRxiv. 2020. [epub, accessed: May 25, 2020]

[19] Guo L, Wei D, Zhang X, et al. Clinical Features Predicting Mortality Risk in Patients With Viral Pneumonia: The MuLBSTA Score. Front Microbiol. 2019; 10: 2752.

[20] Wynants L, Van Calster B, Bonten MMJ, et al. Prediction models for diagnosis and prognosis of covid-19 infection: systematic review and critical appraisal. BMJ. 2020; 369: m1328.

[21] Ji D, Zhang D, Xu J, et al. Prediction for Progression Risk in Patients with COVID-19 Pneumonia: the CALL Score. Clin Infect Dis. 2020. [epub, accessed: May 25, 2020]

[22] Liu X, Zhou H, Zhou Y, et al. Risk factors associated with disease severity and length of hospital stay in COVID-19 patients. J Infect. 2020. [epub, accessed: May 25, 2020]
[23] Zheng Z, Peng F, Xu B, et al. Risk factors of critical \& mortal COVID-19 cases: A systematic literature review and meta-analysis. J Infect. 2020. [epub, accessed: May 25, 2020]

[24] NIH. COVID-19 Treatment Guidelines. Available from: https:// www.covid19treatmentguidelines.nih.gov/ [accessed: May 25, 2020]

[25] IDSA. COVID-19 Guidelines. Available from: https://www.idsociety.org/public-health/COVID-19-Resource-Center/ [accessed: May 25, 2020]

[26] WHO. "Solidarity" clinical trial for COVID-19 treatments. Available from: https://www.who.int/emergencies/diseases/novelcoronavirus-2019/global-research-on-novel-coronavirus-2019ncov/solidarity-clinical-trial-for-covid-19-treatments [accessed: May 25, 2020]

[27] 67/2020. (III. 26.) Korm. rendelet az élet- és vagyonbiztonságot veszélyeztető tömeges megbetegedést okozó humánjárvány megelőzése, illetve következményeinek elhárítása, a magyar állampolgárok egészségének és életének megóvása érdekében elrendelt veszélyhelyzet során történő gyógyszerellátással kapcsolatos intézkedésekről. Available from: https://net.jogtar.hu/jogszabaly?docid=a2000067.kor [accessed: May 25, 2020]

[28] Vijayvargiya P, Garrigos Z, Castillo Almeida N, et al. Treatment Considerations for COVID-19: A Critical Review of the Evidence (or Lack Thereof). Mayo Clin Proc. 2020. [epub, accessed: May 25, 2020]

[29] Liu J, Cao R, Xu M, et al. Hydroxychloroquine, a less toxic derivative of chloroquine, is effective in inhibiting SARS-CoV-2 infection in vitro. Cell Discov. 2020; 6: 16.

[30] Gao J, Tian Z, Yang X. Breakthrough: Chloroquine phosphate has shown apparent efficacy in treatment of COVID-19 associated pneumonia in clinical studies. Biosci Trends. 2020; 14(1): 72-73.

[31] Gautret P, Lagier JC, Parola P, et al. Hydroxychloroquine and azithromycin as a treatment of COVID-19: results of an openlabel non-randomized clinical trial. Int J Antimicrob Agents. 2020. [epub, accessed: May 25, 2020]

[32] Sanders JM, Monogue ML, Jodlowski TZ, et al. Pharmacologic treatments for coronavirus disease 2019 (COVID-19): A review. JAMA. 2020. [epub, accessed: May 25, 2020]

[33] Tang W, Cao Z, Han M, et al. Hydroxychloroquine in patients with mainly mild to moderate coronavirus disease 2019: open label, randomised controlled trial. BMJ. 2020; 369: m1849.

[34] Geleris J, Sun Y, Platt J, et al. Observational Study of Hydroxychloroquine in Hospitalized Patients with Covid-19. N Engl J Med. 2020. [epub, accessed: May 25, 2020]

[35] Rosenberg ES, Dufort EM, Udo T, et al. Association of Treatment With Hydroxychloroquine or Azithromycin With In-Hospital Mortality in Patients With COVID-19 in New York State. JAMA. 2020. [epub, accessed: May 25, 2020]

[36] Mehra MR, Desai SS, Ruschitzka F et al. Hydroxychloroquine or chloroquine with or without a macrolide for treatment of COVID-19: a multinational registry analysis. Lancet. 2020. [epub, accessed: May 25, 2020]

[37] Savarino A, Tarek M. Pharmacokinetic bases of the hydroxychloroquine response in COVID-19: implications for therapy and prevention. medRxiv. 2020. [epub, accessed: May 25, 2020]

[38] Wu J, Li W, Shi X, et al. Early antiviral treatment contributes to alleviate the severity and improve the prognosis of patients with novel coronavirus disease (COVID-19). J Intern Med. 2020. [epub, accessed: May 25, 2020]

[39] Hung IF-N, Lung K-C, Tso EY-K, et al. Triple combination of interferon beta-1b, lopinavir-ritonavir, and ribavirin in the treatment of patients admitted to hospital with COVID-19: an openlabel, randomised, phase 2 trial. Lancet. 2020. [epub, accessed: May 25, 2020]

[40] Cao B, Wang Y, Wen D, et al. A Trial of Lopinavir-Ritonavir in Adults Hospitalized with Severe Covid-19. N Engl J Med. 2020; 382(19): 1787-1799. 
[41] Schoergenhofer C, Jilma B, Stimpfl T, et al. Pharmacokinetics of Lopinavir and Ritonavir in Patients Hospitalized With Coronavirus Disease 2019 (COVID-19). Ann Intern Med. 2020. [epub, accessed: May 25, 2020]

[42] Wang Y, Zhang D, Du G, et al. Remdesivir in adults with severe COVID-19: a randomised, double-blind, placebo-controlled, multicentre trial. Lancet. 2020; 395(10236): 1569-1578.

[43] Li L, Li R, Wu Z, et al. Therapeutic strategies for critically ill patients with COVID-19. Ann Intensive Care. 2020; 10(1): 45.

[44] Hoffmann M, Kleine-Weber H, Schroeder S, et al. SARS-CoV-2 Cell Entry Depends on ACE2 and TMPRSS2 and Is Blocked by a Clinically Proven Protease Inhibitor. Cell. 2020; 181(2): 271-280 e278.

[45] Beigel JH, Tomashek KM, Dodd LE, et al. Remdesivir for the Treatment of Covid-19 - Preliminary Report. N Engl J Med. 2020. [epub, accessed: May 25, 2020]

[46] Ye Q, Wang B, Mao J. The pathogenesis and treatment of the 'Cytokine Storm' in COVID-19. J Infect. 2020; 80(6): 607-613.

[47] Lakatos B, Gopcsa L, Gondos E, et al. Anti-cytokine therapy in novel coronavirus disease (COVID-19) - the first administration of tocilizumab in Hungary at a department of infectology. [Citokinellenes terápia az új típusú koronavírus okozta megbetegedés (COVID-19) kezelésében - tocilizumab elsőként való alkalmazása egy hazai infektológiai osztályon]. Orv Hetil. 2020. [in press, Hungarian]

[48] Cantini F, Niccoli L, Matarrese D, et al. Baricitinib therapy in COVID-19: A pilot study on safety and clinical impact. J Infect. 2020. [epub, accessed: May 25, 2020]

[49] Treon S, Castillo J, Skarbnik A, et al. The BTK-inhibitor ibrutinib may protect against pulmonary injury in COVID-19 infected patients. Blood. 2020. [epub, accessed: May 25, 2020]

[50] Thibaud S, Tremblay D, Bhalla S, et al. Protective Role of BTK Inhibitors in Patients with Chronic Lymphocytic Leukemia and COVID-19. Br J Haematol. 2020. [epub, accessed: May 25, 2020]

[51] Xie Y, Cao S, Dong H, et al. Effect of regular intravenous immunoglobulin therapy on prognosis of severe pneumonia in patients with COVID-19. J Infect. 2020. [epub, accessed: May 25, 2020]

[52] Duan K, Liu B, Li C, et al. Effectiveness of convalescent plasma therapy in severe COVID-19 patients. Proc Natl Acad Sci U S A. 2020; 117(17): 9490-9496.

[53] Rajendran K, Krishnasamy N, Rangarajan J, et al. Convalescent plasma transfusion for the treatment of COVID-19: Systematic review. J Med Virol. 2020. [epub, accessed: May 25, 2020]

[54] HVG. Öt nap után lekerült a lélegeztetőgéprôl az első plazmaterápiával kezelt beteg. Available from: https://hvg.hu/itthon/20200509_valyinagy_istvan_interju_delpesticentrumkorhaz_foigazgato_verplazmaterapia_innovativ_terapia_koronavirus. [accessed: May 25, 2020]

[55] Lekerült a lélegeztetőgépről egy COVID-19 beteg a vérplazmaterápia után a Semmelweis Egyetemen. Available from: https:// semmelweis.hu/hirek/2020/05/13/lekerult-a-lelegeztetogeprola-covid-19-beteg-a-verplazmaterapianak-koszonhetoen-asemmelweis-egyetemen/. [accessed: May 25, 2020]

[56] Zhao RC. Stem cell-based therapy for coronavirus disease 2019. Stem Cells Dev. 2020. [epub, accessed: May 25, 2020]

[57] Zumla A, Wang FS, Ippolito G, et al. Reducing mortality and morbidity in patients with severe COVID-19 disease by advancing ongoing trials of Mesenchymal Stromal (stem) Cell (MSC) therapy - achieving global consensus and visibility for cellular host-directed therapies. Int J Infect Dis. 2020. [epub, accessed: May 25, 2020]

[58] Bari E, Ferrarotti I, Saracino L, et al. Mesenchymal Stromal Cell Secretome for Severe COVID-19 Infections: Premises for the Therapeutic Use. Cells. 2020; 9(4): 1-24.

[59] Rogers CJ, Harman RJ, Bunnell BA, et al. Rationale for the clinical use of adipose-derived mesenchymal stem cells for COVID-19 patients. J Transl Med. 2020; 18(1): 203.
[60] Leung W, Soh TG, Linn YC, et al. Succesful manufacturing of clinical-grade SARS-CoV-2 specific T cells for adoptive cell therapy. medRxiv. 2020. [epub, accessed: May 25, 2020]

[61] Cevik M, Bamford CGG, Ho A. COVID-19 pandemic - a focused review for clinicians. Clin Microbiol Infect. 2020. [epub, accessed: May 25, 2020]

[62] Thachil J, Tang N, Gando S, et al. ISTH interim guidance on recognition and management of coagulopathy in COVID-19. J Thromb Haemost. 2020; 18(5): 1023-1026.

[63] Casini A, Alberio L, Angelillo-Scherrer A, et al. Thromboprophylaxis and laboratory monitoring for in-hospital patients with COVID-19 - a Swiss consensus statement by the Working Party Hemostasis. Swiss Med Wkly. 2020; 150: w20247.

[64] Zhai Z, Li C, Chen Y, et al. Prevention and Treatment of Venous Thromboembolism Associated with Coronavirus Disease 2019 Infection: A Consensus Statement before Guidelines. Thromb Haemost. 2020. [epub, accessed: May 25, 2020]

[65] Bikdeli B, Madhavan MV, Jimenez D, et al. COVID-19 and thrombotic or thromboembolic disease: Implications for prevention, antithrombotic therapy, and follow-up. J Am Coll Cardiol. 2020. [epub, accessed: May 25, 2020]

[66] Barnes G, Burnett A, Allen A, et al. Thromboembolism and anticoagulant therapy during the COVID-19 pandemic: Interim clinical guidance from the anticoagulation forum. J Thromb Thrombolysis. 2020. [epub, accessed: May 25, 2020]

[67] EMMI. Egészségügyi Szakmai Kollégium Hematológiai és Transzfuziológiai Tagozatának és munkacsoportjának ajánlása COVID19 eljárásrenddel kapcsolatban. 2020. [epub, accessed: May 25, 2020]

[68] Willan J, King AJ, Hayes S, et al. Care of haematology patients in a COVID-19 epidemic. Br J Haematol. 2020; 189(2): 241-243.

[69] Mussetti A, Maluquer C, Albasanz-Puig A, et al. Handling the COVID-19 pandemic in the oncological setting. Lancet Haematol. 2020; 7(5): e365-e366.

[70] He Y, Lin Z, Tang D, et al. Strategic plan for management of COVID-19 in paediatric haematology and oncology departments. Lancet Haematol. 2020; 7(5): e359-e362.

[71] Sainati L, Biffi A. How we deal with the COVID-19 epidemic in an Italian paediatric onco-haematology clinic located in a region with a high density of cases. Br J Haematol. 2020; 189(4): 640-642.

[72] von Lilienfeld-Toal M, Vehreschild JJ, Cornely O, et al. Frequently asked questions regarding SARS-CoV-2 in cancer patients - recommendations for clinicians caring for patients with malignant diseases. Leukemia. 2020. [epub, accessed: May 25, 2020]

[73] Al Saleh AS, Sher T, Gertz MA. Multiple Myeloma in the Time of COVID-19. Acta Haematol. 2020. [epub, accessed: May 25, 2020]

[74] Raza A, Assal A, Ali AM, et al. Rewriting the rules for care of MDS and AML patients in the time of COVID-19. Leuk Res Rep. 2020. [epub, accessed: May 25, 2020]

[75] Perini GF, Fischer T, Gaiolla RD, et al. How to manage lymphoid malignancies during novel 2019 coronavirus (CoVid-19) outbreak: a Brazilian task force recommendation. Hematol Transfus Cell Ther. 2020. [epub, accessed: May 25, 2020]

[76] Ljungman P, Mikulska M, de la Camara R, et al. The challenge of COVID-19 and hematopoietic cell transplantation; EBMT recommendations for management of hematopoietic cell transplant recipients, their donors, and patients undergoing CAR T-cell therapy. Bone Marrow Transplant. 2020. [epub, accessed: May 25, 2020]

[77] Paul S, Rausch CR, Jain N, et al. Treating Leukemia in the Time of COVID-19. Acta Haematol. 2020. [epub, accessed: May 25, 2020]

[78] Weinkove R, McQuilten ZK, Adler J, et al. Managing haematology and oncology patients during the COVID-19 pandemic: interim consensus guidance. Med J Aust. 2020. [epub, accessed: May 25, 2020]

[79] Gavillet M, Carr Klappert J, Spertini O, et al. Acute leukemia in the time of COVID-19. Leuk Res. 2020; 92: 106353.

[80] Terpos E, Engelhardt M, Cook G, et al. Management of patients with multiple myeloma in the era of COVID-19 pandemic: a con- 
sensus paper from the European Myeloma Network (EMN). Leukemia. 2020. [epub, accessed: May 25, 2020]

[81] EMMI. Egészségügyi Szakmai Kollégium Aneszteziológiai és Intenzív Terápiás Tagozatának és munkacsoportjának ajánlása COVID-19 eljárásrenddel kapcsolatban. 2020.

[82] Treibel TA, Manisty C, Burton M, et al. COVID-19: PCR screening of asymptomatic health-care workers at London hospital. Lancet. 2020 ; 395: $1608-1610$.
[83] Black JRM, Bailey C, Przewrocka J, et al. COVID-19: the case for health-care worker screening to prevent hospital transmission. Lancet. 2020; 395: 1418-1420.

[84] Bloch EM, Shoham S, Casadevall A, et al. Deployment of convalescent plasma for the prevention and treatment of COVID-19. J Clin Invest. 2020. [epub, accessed: May 25, 2020]

\section{SZUPPLEMENTUM}

\section{Az egyéni védőfelszerelések helyes felvétele (donning) és levétele (doffing) röviden}

Az egyszer használatos munkaruha felvétele után az erre kijelölt vegyszerekkel szappanos kézmosást vagy bőrfertőtlenítést végzünk, majd arcunkra erősítjük az FFP2/ FFP3 maszkot (donning). Az FFP2/FFP3 maszknak az orrot és a szájat is jól fednie kell, a felhelyezést az áll felől az arc irányába döntve végezzük. Az FFP2/FFP3 maszk akkor illeszkedik jól, ha a légzés nehezítettebbé válik, és az illeszkedés mentén sehol nem érzünk áthúzó levegőáramot. Szakállas férfiaknak érdemes megborotválkozniuk a jobb illeszkedés érdekében, szemüvegeseknek először a maszk illeszkedését kell biztosítaniuk arcukon. Az FFP2/FFP3 maszk elé - annak kontaminációját csökkentendő - sebészi szájmaszkot húzhatunk. Ezután következhet az első kesztyú, majd az overáll vagy köpeny felvétele. Az első kesztyút az overáll/köpeny hosszú szára alá fixálni szükséges a csukló köré tekert ragasztószalaggal. A lábbeli védelmére lábzsákot vagy teljes lábszárvédőt alkalmazhatunk (elérhetőség szerint). Amennyiben az overáll rendelkezik kapucnival, azt fel kell venni, ha nem, hajhálót szükséges viselni. Ezután következik a védőszemüveg, és/vagy az arcpajzs felvétele. A pajzs plexi részének a nyak síkja alá kell érnie. A belső gumikesztyúkre még egy réteg külső gumikesztyüpárt húzunk. Megjegyzendő, hogy a kontaminált zónában a maszkunk ill. arcpajzsunk többé nem érinthetjük, azt a biztonságos zónában szükséges igazítani.

Az egyéni védőfelszerelések eltávolítását az erre kijelölt zónában kell megkezdeni (terminális doffing), „fentről lefelé” ill. „kintről befelé” haladva: a fertőtlenített kesztyűs kezünkkel eltávolítjuk az arcpajzsot és a védőszemüveget (amennyiben ezek az overáll kapucniján voltak fixálva), majd a külső kesztyüt is. A belső kesztyü fertőtlenítése után a csuklótáji ragasztást, majd a köpenyt/overállt is el- távolítjuk, utóbbit testünktől mindvégig elfelé tartva. Az overáll/köpeny megőrzése újrahasznosítás céljából nem javasolt stratégia az egyéni és környezeti kontamináció magas veszélye miatt. A lábzsákok eltávolítását követően eldobjuk a belső kesztyűt, ismételt kézfertőtlenítés történik, és eltávolítjuk az FFP2/FFP3 maszkot. A folyamatot mindenképp kézmosás vagy -fertőtlenítés zárja.

Az igazoltan pozitív betegek ellátása közötti terminális doffing kihagyása bár nem ideális, de az egyéni védőfelszerelések esetleges limitációja mellett elfogadható stratégia (extended wear). Ekkor a külső kesztyűnket cseréljük csupán, a csere között a belső kesztyűt az erre kijelölt fertőtlenítőszerrel fertőtlenítjük. A fonendoszkóp használatának létjogosultsága kérdéses, mivel a COVID-19 felismerésében vagy követésében a mellkasi hallgatózásnak csekély szerepe van. Kontaminációra magas rizikójú, általában szabadon maradó felszín a lábbeli és a zokni kilógó része, mindkét lábszár köpeny használata esetén, a fedetlen nyak- és válltájék, a csuklók, nők esetében a nem védett hosszú haj. Ékszert, órát, lógó fülbevalót nem szabad viselni a védőfelszerelés alatt sem. A mobiltelefon használata kontaminált helyen lehetőség szerint kerülendő, amennyiben pl. akut szituáció miatt ezt mégis szükséges megtennünk, úgy a telefont a beszélgetés végeztével az erre kijelölt felületfertőtlenítővel kezelni kell.

\section{Források}

https://www.who.int/csr/resources/publications/putontakeoffPPE/en/

https://med.emory.edu/departments/medicine/divisions/infectious-diseases/serious-communicable-diseases-program/covid-19-resources/index.html

A cikk a Creative Commons Attribution 4.0 International License (https://creativecommons.org/licenses/by/4.0/) feltételei szerint publikált Open Access közlemény, melynek szellemében a cikk bármilyen médiumban szabadon felhasználható, megosztható és újraközölhető, feltéve, hogy az eredeti szerző és a közlés helye, illetve a CC License linkje és az esetlegesen végrehajtott módosítások feltüntetésre kerülnek. (SID_1) 